\title{
The aggressive nature of some urban springs in Dschang and suggested corrections prior to distribution
}

\author{
T. KAMGAING $^{1 *}$, F. M. FONTEH ${ }^{2}$, A. MVONDO ZE ${ }^{3}$, V.Y. KATTE ${ }^{2}$ and \\ E.B. $\mathrm{VOFO}^{1}$ \\ ${ }^{1}$ Laboratory of Noxious Chemistry and Environmental Engineering, Faculty of Science, University of \\ Dschang, Cameroon. \\ ${ }^{2}$ Department of Agricultural Engineering, Faculty of Agronomy and Agricultural Sciences, University of \\ Dschang, Cameroon. \\ ${ }^{3}$ Soil Science laboratory, Faculty of Agronomy and Agricultural Sciences, University of Dschang, Cameroon. \\ "Corresponding author, Email: theokamgaing@yahoo.fr
}

\begin{abstract}
Many sections of Dschang town do not have pipe-borne water. For domestic purposes, about $25 \%$ of households cover distances of between 500 and 1000 meters to fetch water. The aim of this study is to see the possibility to bring the spring water closer to consumers. Analysis of the water is necessary before such a venture. The physicochemical analysis of spring waters consumed revealed their softness, their low level of mineralization and their aggressive character. Previous study indicated that Escherichia coli was present in those springs with variations from one spring to another. Considering the physicochemical and biological aspects of springs, the study proposed that the water be treated with calcium carbonate in order to improve upon the total hardness, total alkalinity and to bring water to the calco-carbonic equilibrium. To disinfect the water, calcium hypochlorite was recommended as well as polyvinyl chloride for the mini distribution network. (C) 2008 International Formulae Group. All rights reserved.
\end{abstract}

Keywords: Langelier Index, calcium carbonate softness, remineralization, calco-carbonic equilibrium, network.

\section{INTRODUCTION}

Dschang is located in the West Province of Cameroon and has a population of about 81,700 (NIS, 2001). It has a sub equatorial type of climate characterised by four months of dry season starting from mid November to mid March and eight months of rainy season from mid March to mid November with an annual rainfall between 1200 and $1800 \mathrm{~mm}$ (Tekoudjou, 2004). The average daily temperature is $20.9{ }^{\circ} \mathrm{C}$ and the average daily humidity ranges from 33 to $98 \%$ (Champaud, 1973). Geologically, Dschang is situated in the central domain of the North Equatorial Pan African range. This range links the Trans Saharan Pan African and the Pan African range of East Africa (Kwekam, 1993). The region has two main rock types: volcanic rocks consisting of porphyric or aphyric basalts and metamorphic rocks mainly of gneiss (Nni et Nyobe, 1995; Tabue, 2000). Minerals in the basalts include biotite, hornblende, augite and apatite (Kwekam, 1993; Nni et Nyobe, 1995). The gneiss contains quartz and feldspars. The feldspars are usually sodium or calcium plagioclase. The chemical composition of water is linked to the mineralogy of rocks and soils of the region (Simo, 2006).

The town has experienced an explosion in population since the creation of a University in the town in 1993 causing an influx of about 15,000 people. However, there has been no increase in the capacity of the water supply in the town, thus many sections of the town do not have pipe-borne water, while some sections with pipe-borne water can go for days without water. 
About $55 \%$ of the population in Dschang rely on spring water for domestic consumption with about $25 \%$ of the population concerned covering distances of between 500 and $1000 \mathrm{~m}$ to fetch the water (Ngomediage, 2001). However, bacteriological studies by Guemuh (2003) indicate that water from some of the springs is not potable. Given the distances some of the users have to cover to fetch poor quality water, it is necessary not only to treat the water but also to increase the accessibility to the water by conveying it closer to the population. This would require that the water should be in calco-carbonic equilibrium such that the conduits will not be corroded by the water. Thus a comparative study of the physico-chemical characteristics of spring waters, pipe borne water, well water and bottled water was carried out. From these an economical correction for the spring water was proposed as well as recommendation of a suitable piping material.

The aim of this study was therefore to determine the chemical composition of spring water consumed in Dschang, so as to suggest a simple corrective treatment technique before it is distributed to the population. It would not be economic to construct a distribution network for every spring, so the study explored the regrouping of springs based on their proximity and biological quality to supply the proposed distribution networks.

\section{MATERIALS AND METHODS Sample collection}

Water samples were collected in plastic bottles at the beginning of February in the dry season from each of the eight water sources (16 samples during the whole campaign). The water samples were collected from five springs, pipe borne water from the National water utility company (SNEC) which is a major distribution system, well water and from Scanwater located at the periphery of the town with the water source being from a borehole and has a mini distribution system. SNEC water was sampled at the water treatment station (2 samples). A drop of chloroform was added to each bottle to stabilise it. Bottled waters were bought and analysed in the same conditions; where necessary, it underwent a dilution before analysis. Table 1 gives the description of water sources while figure 1 shows their location.

Equilibrium pH and the Langelier Index

Water is termed aggressive when it reacts with calcium carbonate according to the following equation (1).

$\mathrm{CaCO}_{3}+\mathrm{H}_{2} \mathrm{CO}_{3} \leftrightarrow \mathrm{Ca}\left(\mathrm{HCO}_{3}\right)_{2}$

It is termed scaling or incrusting if calcium carbonate precipitates (Legrand and Poirier, 1976).

Water that is neither aggressive nor scaling is therefore at calco-carbonic equilibrium as shown in equation 1 . This is derived from the three simultaneous equilibrium equations given below.

$$
\begin{array}{lll}
\mathrm{H}_{2} \mathrm{CO}_{3} \leftrightarrow \mathrm{H}^{+}+\mathrm{HCO}_{3}^{-} & \mathrm{K}_{1} & -- \text { (2) } \\
\mathrm{HCO}_{3}^{-} \leftrightarrow \mathrm{H}^{+}+\mathrm{CO}_{3}^{2-} & K_{2} & ---(3) \\
\mathrm{CaCO}_{3} \leftrightarrow \mathrm{Ca}^{2+}+\mathrm{CO}_{3}^{2-} & K_{S} & ---(4)
\end{array}
$$

The equilibrium $\mathrm{pH}\left(\mathrm{pH}_{\mathrm{eq}}\right)$ is the $\mathrm{pH}$ corresponding to equilibrium situation which is different from the real $\mathrm{pH}\left(\mathrm{pH}_{\mathrm{r}}\right)$. The equilibrium $\mathrm{pH}$ is obtained from the combination of equations 3 and 4 given above.

$$
\begin{gathered}
p H_{e q}=p K_{2}^{\prime}-p K_{s}^{\prime}-\log \left(\mathrm{Ca}^{2+}\right)-\log \left(\mathrm{HCO}_{\xi}\right) \\
K^{\prime} \text { 's are apparent constants which }
\end{gathered}
$$
depend on the ionic strength (I) of the medium (Table 2)

The values of $p K_{1}, p K_{2}$ and $p K_{s}$ at different temperatures were calculated from the empirical laws of Plummer and Busenberg, (1982). The calculations show that the values obtained are essentially the same with those from standard values at $25^{\circ} \mathrm{C}$.

The Langlier index $\mathrm{I}_{\mathrm{L}}$ is used to determine the degree of aggressivity or scaling of the water. It is obtained from $\mathrm{I}_{\mathrm{L}}=\mathrm{pH}_{\mathrm{r}}-\mathrm{pH}_{\text {eq }}$. Therefore, water can be classified as either aggressive $\left(\mathrm{I}_{\mathrm{L}}<0\right)$, at equilibrium $\left(\mathrm{I}_{\mathrm{L}}=0\right)$ or scaling $\left(\mathrm{I}_{\mathrm{L}}>0\right)$.

\section{Measurement of $\mathrm{pH}$ and some cations}

- The $\mathrm{pH}$ was measured with a $\mathrm{pH}$ meter of the CONSORT CG822 type which has a combined electrode at a temperature of $20^{\circ} \mathrm{C}$ which is practically the ambient temperature of water.

$$
-\mathrm{Ca}^{2+}, \mathrm{Mg}^{2+}, \mathrm{K}^{+}, \mathrm{Na}^{+}
$$




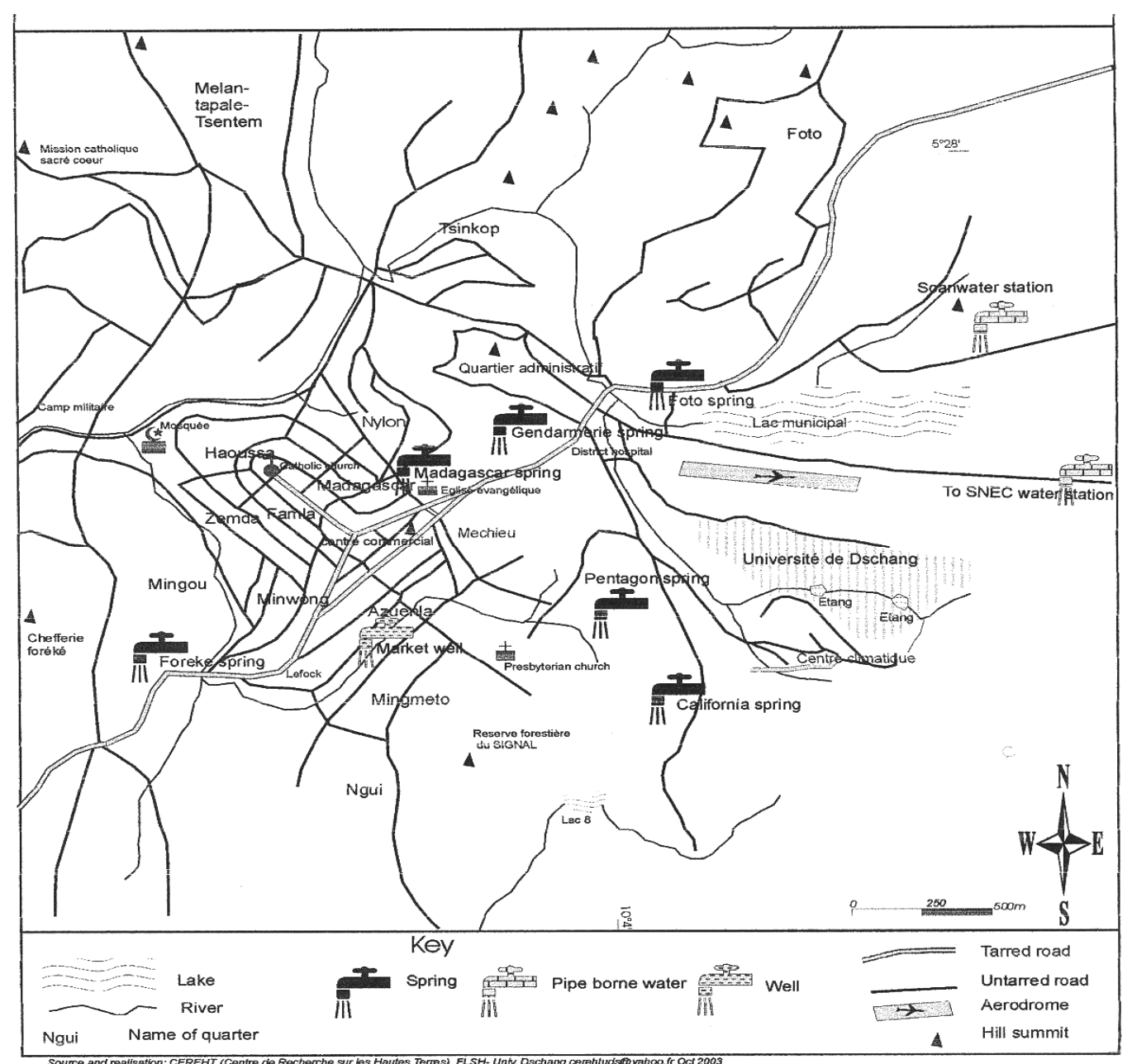

Figure 1: Map of Dschang showing the different water sources analysed.

Table 1: Description of the water sources.

\begin{tabular}{lllll}
\hline Water source & Location & $\begin{array}{l}\text { Flow rate } \\
(\mathbf{l} / \mathbf{s})\end{array}$ & $\begin{array}{l}\text { Method of } \\
\text { distribution }\end{array}$ & Remarks \\
\hline $\mathrm{S}_{1}$ (California) & Paidground valley & 0.06 & None & Non harnessed spring \\
\hline $\mathrm{S}_{2}$ (Pentagon) & Paidground (behind CNPS) & - & None & $\begin{array}{l}\text { Harnessed spring, located in a } \\
\text { high density area }\end{array}$ \\
\hline $\mathrm{S}_{3}$ (Gendarmerie) & $\begin{array}{l}\text { Administrative centre } \\
\text { (Gendarmerie camp) }\end{array}$ & 0.42 & None & $\begin{array}{l}\text { Spring in moderate habitat and } \\
\text { agriculture practiced around. Pit } \\
\text { been constructed } \\
\text { toilets have } \\
\end{array}$ \\
& Madagascar & & upstream recently \\
\hline $\mathrm{S}_{4}$ (Madagascar) & Behind the EEC & 0.15 & None & $\begin{array}{l}\text { Harnessed free flowing spring } \\
\text { without pumping facilities } \\
\text { located in a rocky environment }\end{array}$ \\
\hline $\mathrm{S}_{5}$ (Foreke) & $\begin{array}{l}\text { Foreke } \\
\text { Opposite Edoc-Eter) }\end{array}$ & - & None & $\begin{array}{l}\text { Spring with agricultural activity } \\
\text { in the environs }\end{array}$ \\
\hline SNEC & Batsingla & & Pipe network & $\begin{array}{l}\text { Conventional water treatment } \\
\text { with water from a river }\end{array}$ \\
\hline Scanwater & Tsingbing & & Pipe network & Water from a borehole \\
\hline Well & Ngui Market & None & $\begin{array}{l}\text { Covered well with pump } \\
\text { installed. }\end{array}$ \\
\hline
\end{tabular}


Table 2: Relationship between the thermodynamic and apparent constants.

\begin{tabular}{|c|c|}
\hline$p K_{1}^{\prime}=p K_{1}-\varepsilon$ & \\
\hline$p K_{2}^{\prime}=p K_{2}-2 \varepsilon$ & $\varepsilon=\frac{\sqrt{ } I}{}$ \\
\hline$p K_{s}^{\prime}=p K_{s}-4 \varepsilon$ & $1+1.4 \sqrt{I}$ \\
\hline
\end{tabular}

After sampling, cations were analysed 24 hours later at the Laboratory of Soil Chemistry with an atomic absorption spectrophotometer manufactured by SHIMADZU type AA670/GV-8. It is equipped with a cathodic lamp of calcium, magnesium, potassium or sodium and with a host of nebular oxy-acetylene burner. The following wavelengths in $\mathrm{nm}$ were used; $\mathrm{Ca}$ (422.7), $\mathrm{Mg}$ (285.2), $\mathrm{K}$ (766.5) and $\mathrm{Na}$ (589.0).

- Iron and Aluminium ions: these elements were titrated using an UV spectrophotometer at the following wavelengths in nm: Iron (530) and Aluminium (665).

\section{Determination of Nitrates}

The Kjeldal method (Rodier, 1996) was used to test for total nitrogen in water. The sum of free ammonia and nitrogen compounds were converted to ammonium bisulphate by shaking the aliquot with a solution of concentrated $\mathrm{H}_{2} \mathrm{SO}_{4}$. A reduction of the $\mathrm{NO}_{3}{ }^{-}$ and $\mathrm{NO}_{2}^{-}$with $\mathrm{Na}_{2} \mathrm{~S}_{2} \mathrm{O}_{3}$ in the presence of salicylic acid followed and then there was the distillation of the ammonium salt in the form of ammonia. Ammonia was then titrated with a standard $0.1 \mathrm{~N} \mathrm{H}_{2} \mathrm{SO}_{4}$.

Given that a water sample of $25 \mathrm{ml}$ volume was used, the nitrate was obtained by multiplying the volume of $0.1 \mathrm{~N} \mathrm{H}_{2} \mathrm{SO}_{4}$ used in titrating the ammonia by 4.5 (Twort et al., 1982; Fletcher,1986).

Determination of Chlorides, Sulphates, Alkalinity and Electrical conductivity

- The titration of chloride was carried out using the Mohr method (Vogel, 1962)

- Sulphates were determined by agitating the samples with barium chloride for two minutes until the appearance of a whitish precipitate which is indicative of the presence of sulphates.

Hydrogencarbonate $\left(\mathrm{HCO}_{3}{ }^{-}\right)$ determines the total alkalinity of water and is a component of the calco-carbonic equilibrium (equation 1).

To determine the alkalinity, a known volume of sample aliquot was titrated with standardized $\mathrm{HCl}$ to the end point with colour change from blue to steel grey with a $\mathrm{pH} 4.5$ indicator.

- The Electrical conductivity was measured using a WTW type LF521 conductivity meter.

\section{Determination of Hardness}

The water hardness refers to the total amount of calcium and magnesium. It could be expressed either in $\mathrm{mol} / \mathrm{L}$, meq/L, French degree $\left({ }^{\circ} \mathrm{F}\right)$ and so forth. $1 \mathrm{meq}=5^{\circ} \mathrm{F}$

\section{E. coli count}

We referred to previous study done by Guemuh (2003).

\section{RESULTS}

Physico-chemical characteristics

$$
\text { Results on physico-chemical }
$$

characteristics of water are shown on table 3. As far as bottled water is concerned, results were practically the same as indicated on the bottle.

Calcium $\left(\mathrm{Ca}^{2+}\right)$ levels range from a minimum of $0.4 \mathrm{mg} / \mathrm{L}$ in spring $\mathrm{S}_{1}$ and in SNEC water to a maximum of $3.2 \mathrm{mg} / \mathrm{L}$ in spring $\mathrm{S}_{2}$. Spring $\mathrm{S}_{5}$ and scanwater have practically the same amount of calcium (0.6$0.8 \mathrm{mg} / \mathrm{L})$. This element is more concentrated in the well $(9.6 \mathrm{mg} / \mathrm{L})$. However bottled waters have a great amount of calcium $(32-60 \mathrm{mg} / \mathrm{L})$.

The minimum amount of magnesium $\left(\mathrm{Mg}^{2+}\right)$ is found in springs $\mathrm{S}_{5}(1.1 \mathrm{mg} / \mathrm{L})$ and $\mathrm{S}_{1}(1.3 \mathrm{mg} / \mathrm{L})$ while the maximum is recorded in springs $\mathrm{S}_{2}, \mathrm{~S}_{3}$ and scanwater (2 $\left.\mathrm{mg} / \mathrm{L}\right)$. The well, the spring $\mathrm{S}_{4}$ and the SNEC water have the same level of magnesium $(1.7 \mathrm{mg} / \mathrm{L})$; Minerah and Tangui (bottled waters) are the most concentrated in magnesium (13-21 $\mathrm{mg} / \mathrm{L})$. 
Table 3: Physico-chemical characteristics of the various water sources.

\begin{tabular}{|c|c|c|c|c|c|c|c|c|c|c|c|c|}
\hline \multirow[t]{2}{*}{ Samples } & \multicolumn{8}{|c|}{ Concentrations in $\mathrm{mg} / \mathrm{l}$} & \multirow[t]{2}{*}{ pH } & \multirow{2}{*}{$\begin{array}{c}\mathrm{EC} \\
(\mathrm{mS} / \mathrm{cm})\end{array}$} & \multirow{2}{*}{$\begin{array}{l}\text { Temp. } \\
\left({ }^{\circ} \mathrm{C}\right)\end{array}$} & \multirow{2}{*}{$\begin{array}{c}\text { Hardness } \\
\left({ }^{\circ} \mathbf{F}\right)\end{array}$} \\
\hline & $\mathrm{Ca}^{2+}$ & $\mathrm{Mg}^{2+}$ & $\mathrm{Na}^{+}$ & $\mathbf{K}^{+}$ & $\mathrm{HCO}_{3}^{-}$ & $\mathrm{Cl}^{-}$ & $\mathrm{NO}_{3}{ }^{-}$ & $\mathrm{SO}_{4}{ }^{2-}$ & & & & \\
\hline $\mathrm{S}_{1}$ & 0.4 & 1.3 & 6.9 & Traces & 5.5 & 4.3 & 16.1 & Traces & 5.45 & 0.028 & 19 & 0.7 \\
\hline $\mathrm{S}_{2}$ & 3.2 & 2.0 & 5.5 & 2.3 & 4.3 & 9.9 & 14.3 & Traces & 5.62 & 0.069 & 18.7 & 1.7 \\
\hline $\mathrm{S}_{3}$ & 2.0 & 2.0 & 5.5 & 0.8 & 4.3 & 7.8 & 18.6 & Traces & 6.12 & 0.098 & 19.2 & 1.4 \\
\hline $\mathrm{S}_{4}$ & 1.3 & 1.7 & 6.4 & 1.0 & 5.5 & 6.7 & 14.3 & Traces & 5.50 & 0.040 & 18.8 & 1.1 \\
\hline $\mathrm{S}_{5}$ & 0.6 & 1.1 & 6.7 & 3.9 & 4.3 & 8.5 & 14.3 & Traces & 5.32 & 0.053 & 20 & 0.6 \\
\hline Well & 9.6 & 1.8 & 6.9 & 13.3 & 6.1 & 23.4 & 33.5 & Traces & 5.06 & 0.013 & 19.8 & 3.2 \\
\hline SNEC & 0.4 & 1.7 & 3.7 & 1.10 & 6.1 & 3.6 & 8.8 & Traces & 6.57 & 0.035 & 18.7 & 0.9 \\
\hline Scanwater & 0.8 & 2.0 & 4.1 & 0.8 & 6.1 & 10.6 & 6.2 & Traces & 6.06 & 0.042 & 19.6 & 1.1 \\
\hline Tangui* & 32 & 21 & 1.0 & 10 & 217 & 1.0 & None & 2 & - & - & - & 16.8 \\
\hline Minerah* & 60 & 13 & 40 & 2.0 & 210 & 7.5 & 17.2 & 28 & 7.5 & - & - & 20.4 \\
\hline
\end{tabular}

$*$ Bottled mineral water. Aluminium $\left(\mathrm{Al}^{3+}\right)$ was not detected in all water samples.

Sodium $\left(\mathrm{Na}^{+}\right)$levels ranged from a minimum of $5.5 \mathrm{mg} / \mathrm{L}$ in springs $\mathrm{S}_{2}$ and $\mathrm{S}_{3}$ to a maximum of $6.9 \mathrm{mg} / \mathrm{L}$ in spring $S_{1}$ and the well. The pipe borne waters are less concentrated in sodium $(3.7-4.1 \mathrm{mg} / \mathrm{L})$. Minerah has the greatest level of sodium (40 $\mathrm{mg} / \mathrm{L})$.

Potassium $\left(\mathrm{K}^{+}\right)$was not detected in spring $\mathrm{S}_{1}$. When detected, the lowest value was $0.8 \mathrm{mg} / \mathrm{L}$ (spring $\mathrm{S}_{3}$ and scanwater) and the highest value $(13.3 \mathrm{mg} / \mathrm{L})$ was recorded in the well.

Aluminium $\left(\mathrm{Al}^{3+}\right)$ was not detected in all water samples.

The amount of iron $\left(\mathrm{Fe}^{2+}, \mathrm{Fe}^{3+}\right)$ in water springs was not considerable; it did not exceed $0.2 \mathrm{mg} / \mathrm{L}$ (spring $\mathrm{S}_{2}$ ). The admitted concentration of iron in drinking water is 0.3 $\mathrm{mg} / \mathrm{L}$ (WHO, 1993).

The minimum level of Hydrogencarbonate $\left(\mathrm{HCO}_{3}{ }^{-}\right)$is obtained from springs $\mathrm{S}_{2}, \mathrm{~S}_{3}, \mathrm{~S}_{5}(5.5 \mathrm{mg} / \mathrm{L})$, while the maximum level is recorded with SNEC water, Scanwater and the Well $(6.1 \mathrm{mg} / \mathrm{L})$. However, bottled mineral water are too concentrated in hydrogencarbonate (210- $217 \mathrm{mg} / \mathrm{L})$.

The minimum amount of chloride $\left(\mathrm{Cl}^{-}\right)$ is obtained from SNEC water $(3.6 \mathrm{mg} / \mathrm{L})$ and the maximum level from the well $(23.4 \mathrm{mg} / \mathrm{L})$.

Nitrate $\left(\mathrm{NO}_{3}{ }^{-}\right)$levels ranged from a minimum of $14.3 \mathrm{mg} / \mathrm{L}$ in springs $\mathrm{S}_{2}, \mathrm{~S}_{4}, \mathrm{~S}_{5}$ to a maximum of $33.5 \mathrm{mg} / \mathrm{L}$ in the well water. $S_{1}$ and $S_{3}$ have practically the same amount of nitrate (16.1-18.6 mg/L).

Sulphate $\left(\mathrm{SO}_{4}^{2-}\right)$ was not detected. Only bottled mineral waters have this element: 2 $\mathrm{mg} / \mathrm{L}$ in Tangui and $28 \mathrm{mg} / \mathrm{L}$ in Minerah.
As springs are concerned, the minimum $\mathrm{pH}$ is obtained with spring $\mathrm{S}_{5}$ (5.32) and the maximum with spring $S_{3}(6.12)$.

Electrical conductivity (EC) levels ranged from $0.028 \mathrm{mS} / \mathrm{cm}$ in spring $S_{1}$ to $0.129 \mathrm{mS} / \mathrm{cm}$ with the well water.

The average temperature (Temp) of springs is $19^{\circ} \mathrm{C}$.

Water hardness: The minimum value of hardness is recorded in springs $S_{1}$ and $S_{5}(0.7$ ${ }^{\circ} \mathrm{F}$ ) and the highest value in the well water $\left(3.2^{\circ} \mathrm{F}\right)$. However, bottled waters are harder than the other water sources (16.8- $\left.20.4^{\circ} \mathrm{F}\right)$.

\section{Aggressivity of water sources}

Table 4 shows the Langelier index of springs and the well water, SNEC water and scanwater. Their equilibrium $\mathrm{pH}$ (pHeq) is practically twice the real $\mathrm{pH}(\mathrm{pHr})$. They are extremely aggressive as indicative of the very negative langelier index.

\section{Water network distribution}

Figure 2 gives a simple correction procedure to temper spring water aggressivity.

Figure 3 indicates the distribution of non aggressive spring water in a pipe network.

\section{DISCUSSION}

The following points are discussed in the light of the impact of remineralisation of the springs and the consequences of the aggressive water on conduits and to the end user:

\section{Softness of water}

The softness of water sources is confirmed by the low content of calcium and magnesium as 
Table 4: Langelier Indices of the various water sources.

\begin{tabular}{lcccccccc}
\hline Samples & $\mathbf{I . 1 0}^{\mathbf{3}}(\mathbf{m o l} / \mathbf{l})$ & $\boldsymbol{\varepsilon}$ & $\mathbf{p K}_{\mathbf{1}}{ }^{\prime}$ & $\mathbf{p K}_{\mathbf{2}}{ }^{\prime}$ & $\mathbf{p K}_{\mathbf{s}}{ }^{\prime}$ & $\mathbf{p H}_{\mathbf{r}}$ & $\mathbf{p H}_{\mathbf{e q}}$ & $\mathbf{I}_{\mathbf{L}}$ \\
\hline $\mathrm{S}_{1}$ & 0.47 & 0.021 & 6.33 & 10.29 & 8.40 & 5.45 & 10.93 & -5.48 \\
$\mathrm{~S}_{2}$ & 0.77 & 0.027 & 6.32 & 10.28 & 8.37 & 5.62 & 10.16 & -4.54 \\
$\mathrm{~S}_{3}$ & 0.69 & 0.025 & 6.32 & 10.28 & 8.38 & 5.50 & 10.35 & -4.85 \\
$\mathrm{~S}_{4}$ & 0.62 & 0.024 & 6.32 & 10.28 & 8.38 & 5.15 & 10.43 & -5.28 \\
$\mathrm{~S}_{5}$ & 0.58 & 0.023 & 6.33 & 10.28 & 8.39 & 5.32 & 10.87 & -5.55 \\
Well & 1.60 & 0.038 & 6.31 & 10.25 & 8.33 & 5.06 & 9.54 & -4.48 \\
SNEC & 0.43 & 0.020 & 6.33 & 10.29 & 8.40 & 6.57 & 10.89 & -4.32 \\
Scanwater & 0.56 & 0.023 & 6.33 & 10.28 & 8.39 & 6.06 & 10.59 & -4.53 \\
\hline
\end{tabular}

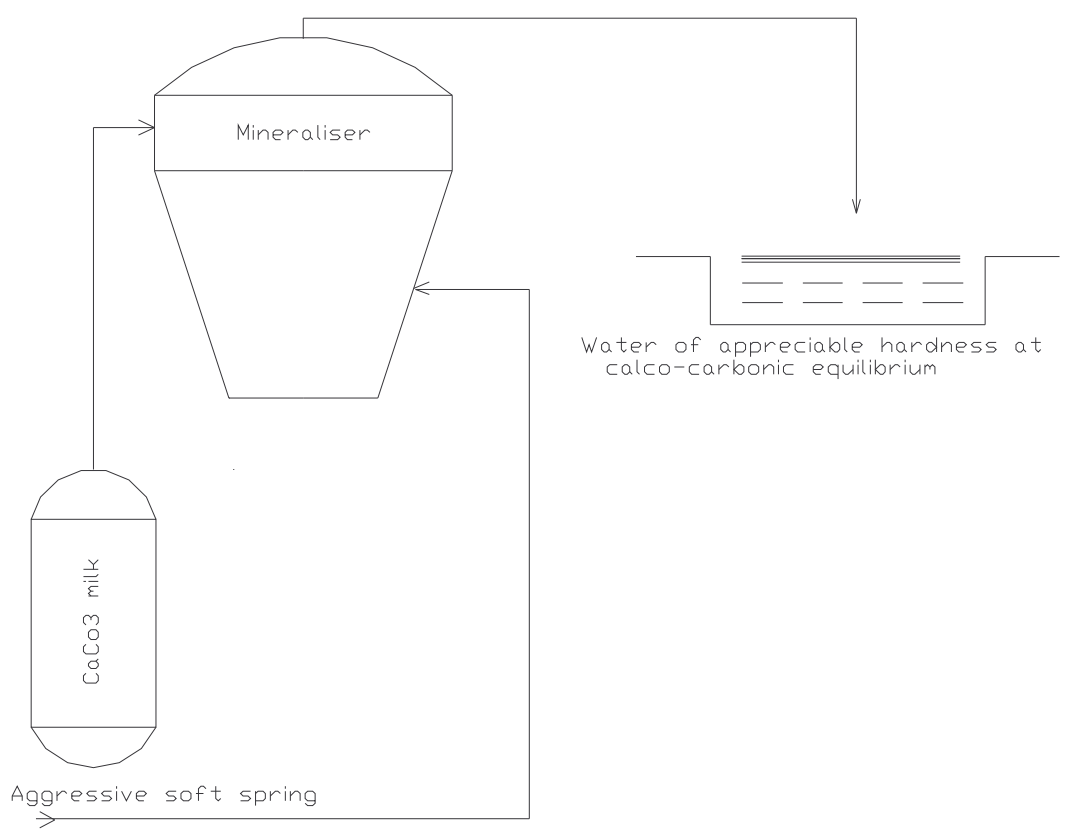

Figure 2: Simple correction procedure for spring water.

well as the total hardness which is less than $1.7^{\circ} \mathrm{F}(0.34 \mathrm{meq})$. This value is 10 times lesser than that admitted by WHO (1997). Calcium and magnesium are beneficial to human beings. The minimum recommended by $\mathrm{CEE}$ (1975) is 10mg/L for calcium, $5 \mathrm{mg} / \mathrm{L}$ for magnesium and a total hardness of $10^{\circ} \mathrm{F}$. The extreme softness of spring waters is typical of the surface water in tropical regions located between latitude 6 and 10 where the climate is characterised by marked changes in the rainy and dry seasons (Guilleret et al., 1990). With such a climate the surface rocks are subjected to high intensity erosion which alters their chemical and mineralogical composition (Mohr et al., 1972). Such a process took place in Africa millions of years ago and resulted in the formation of laterites. As a consequence the waters encountered here are slightly mineralized (Guilleret et al., 1990).

Soft water has the advantage that it is good for washing as it easily forms lather and is also good for cooking vegetables. However, 


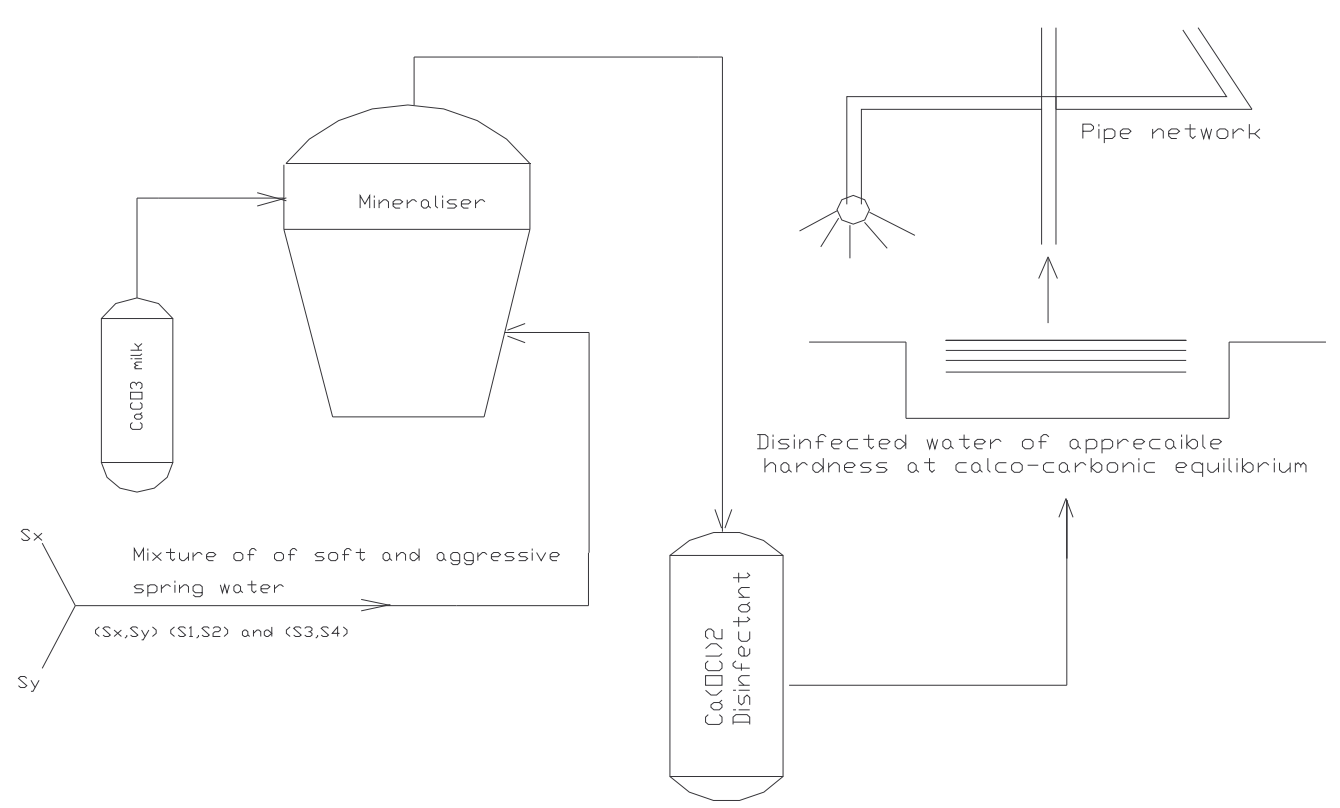

Figure 3: Correction procedure and distribution of spring water in a pipe network.

it has the disadvantage that it corrodes some conduits (Jaeger et al., 2005).

When calcium content of water is very low, metallic conduits are no longer protected by the film of calcium carbonate and are consequently exposed to corrosion (Legrand et Poirier, 1976). Then it is necessary to improve on the amount of calcium before water is conveyed through a distribution network.

\section{Chlorides and Nitrates}

The highest chloride and nitrate contents (23.4 $\mathrm{mg} / \mathrm{L}$ and $33.5 \mathrm{mg} / \mathrm{L}$ respectively) are found in a well located at the centre of a market in a dirty neighbourhood. Wood ash and animal dung are used as agricultural inputs in the immediate vicinity of the spring sources (Vofo, 2001). Knowing that the region has no industries, domestic waste is likely the principal origin of chlorides and nitrates into water sources. An overlapping of the water table and leachete from the septic tanks are possible sources of nitrate and chloride into waters (Moulinier, 1998).

However, nitrates and chlorides do not constitute a threat to health except when they are above $50 \mathrm{mg} / \mathrm{l}$ and $250 \mathrm{mg} / \mathrm{l}$ respectively (WHO, 1997). Above a concentration of 50 $\mathrm{mg} / \mathrm{L}$, chlorides become corrosive in conduits and reservoirs made of mild steel (Rodier, 1984).

\section{Aggressivity of the spring water and the piped supply}

Aggressive and soft water generally corrodes metallic conduits (Guilleret et al., 1990; Kamgaing, 2003; Jaeger et al., 2005). Such water should not be used in domestic equipment like water heaters without treatment to bring it to calco-carbonic equilibrium (Legrand et Poirier, 1981).

For a long time, water distribution networks were made of metallic conduits. The aggressive effect of water on metals such as lead, zinc, copper or steel was ignored. Since the 1970s when the first cases of heavy metal intoxications in drinking water were reported (Collienne and De Graeve, 1973; Rondia and Sartor, 1978), metallic conduits are no longer in current use. They have been replaced by materials made from polymers which are noncorrosive. This change is not yet wide spread in developing countries where most towns still have old pipelines made from lead, copper, cast iron and /or steel. In Dschang, the first water treatment works was built in 1957 with the distribution network of cast iron. An extension to this was done in 1982 with the network of PVC. Like in most Cameroonian 
towns, Dschang inclusive, most of the water users are confronted with problems of taste, colour, and odour of the water they consume. Often the water is yellowish which results from the corrosion of the metallic conduit. When stagnant for sometime settleable flocs are noticed which is certainly goethite or lepidocrite $(\mathrm{FeOOH})$ associated to $\mathrm{Fe}(\mathrm{OH})_{3}$ hydroxides (Kamgaing, 1993). Once this corrosion takes place by such aggressive water, the conduits become a receptacle for bacteria (gallionella). Furthermore, certain micro-organisms make use of $\mathrm{Fe}^{2+}$ as a vital element and also for energy production through the oxidation reaction below:

$\mathrm{Fe}^{2+} \rightarrow \mathrm{Fe}^{3+}+\mathrm{e}^{2+}+11.5 \mathrm{Kcal}$ (Rheinheimer, 1980) (6).

The energy gained as a result of this transformation is low and these microorganisms have to further oxidise a relatively appreciable quantity of iron which can lead to the formation of ferrous hydroxide $\mathrm{Fe}(\mathrm{OH})_{3}$; As such conduit obstruction could be the consequence of a highly aggressive water and secondly the multiplication of either autotrophic or heterotrophic bacteria.
It is observed that a reverse mechanism also takes place by other organisms such as the vibros which reduce $\mathrm{Fe}^{3+}$ to $\mathrm{Fe}^{2+}$ (Jones et al., 1993) and as such they are in a perfect symbiosis.

\section{Simultaneous water mineralization and reduction in aggressivity}

The spring sources are very soft, slightly mineralised and very aggressive. Such waters should not flow through metallic conduits without treatment. It would be economic if this treatment simultaneously satisfies the hardness and the alkalinity as well as the calco-carbonic equilibrium.

Using the diagram $\mathrm{CO}_{2 \mathrm{~T}}-\mathrm{Ca}^{2+}$ (Legrand et al. 1981) a simple chemical correction procedure is proposed. $\mathrm{CO}_{2 \mathrm{~T}}$ is the total $\mathrm{CO}_{2}$ i.e the total amount of $\mathrm{H}_{2} \mathrm{CO}_{3}$, $\mathrm{HCO}_{3}{ }^{-}, \mathrm{CO}_{3}{ }^{2-}$. In this diagram the addition of $\mathrm{CaCO}_{3}$ to corrosive water pushes it from point $\mathrm{M}$ to point $\mathrm{P}$ through a slope of gradient 1 where the water is at calco-carbonic equilibrium (figure 4). At this point the total hardness (TH) and the total alkalinity (TA) have increased by the same unit.

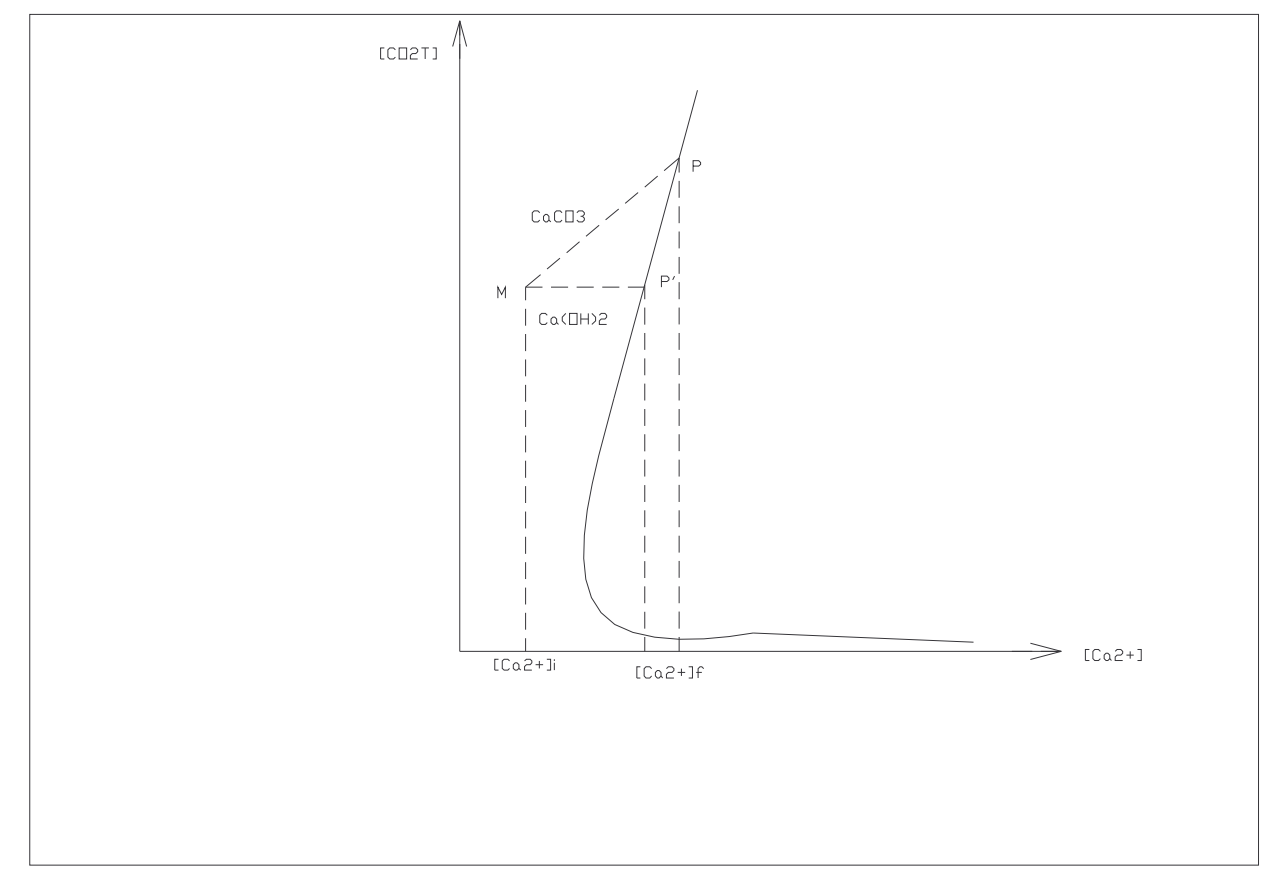

Figure 4: Aggressive water in contact with $\mathrm{CaCO}_{3}$. 
The calco-carbonic curve is a function of the amount of characteristic ions found in water and can quickly be obtained through a computer model developed by Marchand et al. (1985). All waters having the same value of $\lambda$ $(\lambda=0.5(\mathrm{~N}-\mathrm{P}))$ have a similar calco-carbonic curve in the diagram $\mathrm{CO}_{2 \mathrm{~T}}-\mathrm{Ca}^{2+} . \mathrm{N}$ and $\mathrm{P}$ represent the amount of characteristic anions and the amount of characteristic cations respectively. Characteristic ions are those different from $\mathrm{Ca}^{2+}, \mathrm{HCO}_{3}{ }^{-}$and $\mathrm{CO}_{3}{ }^{2-}$ found in all natural water.

For purposes of economy, the amount of $\mathrm{CaCO}_{3}$ needed would be that which is just sufficient to move the point $\mathrm{M}$ to the point $\mathrm{P}$ (see figure 4).

$\left[\mathrm{CaCO}_{3}\right]=\left[\mathrm{Ca}^{2+}\right]_{\mathrm{f}}-\left[\mathrm{Ca}^{2+}\right]_{\mathrm{I}}---$-------- -- (7)

It is observed that treatment with lime will move the point $\mathrm{M}$ rather to $\mathrm{P}^{\prime}$. At points $\mathrm{P}$ and $\mathrm{P}^{\prime}$ an increase in $\mathrm{HCO}_{3}^{-}$is dependent on the carbonic acid content of the water as shown in the equations 8 and 9 .

$$
\begin{aligned}
& \mathrm{CaCO}_{3}+\mathrm{H}_{2} \mathrm{CO}_{3} \leftrightarrow \mathrm{Ca}^{2+}+2 \mathrm{HCO}_{3}^{--}(8) \\
& \mathrm{Ca}(\mathrm{OH})_{2}+2 \mathrm{H}_{2} \mathrm{CO}_{3} \leftrightarrow \mathrm{Ca}^{2+}+2 \mathrm{HCO}_{3}^{-}+2 \mathrm{H}_{2} \mathrm{O}
\end{aligned}
$$

From these equations, it is evident that to increase the alkalinity by two moles of $\mathrm{HCO}_{3}^{-}$, the $\mathrm{Ca}(\mathrm{OH})_{2}$ uses 2 moles of carbonic acid meanwhile $\mathrm{CaCO}_{3}$ uses only one mole of the acid. Consequently $\mathrm{CaCO}_{3}$ improves better the hardness and the alkalinity of the water.

Figure 2 gives an idea of the process adopted. The corrosive water and $\mathrm{CaCO}_{3}$ milk flow into the mineralising tank in opposite directions. After a maximum of two hours, the water pumped out is at calco-carbonic equilibrium as well as sufficiently rich in calcium and hydrogencarbonate. The $\mathrm{CaCO}_{3}$ milk is prepared from treated non corrosive water so as not to alter the required dosage required in the mineralising tank. The conduit leading to the mineralising tank must be made of non corrosive material such as PVC.

Alkalinity, aggressivity and hardness are not the only parameters to be corrected, but are the main parameters which influence directly the calco-carbonic equilibrium and consequently the corrosion of metallic conduits.

\section{Local pipe network}

The possibility of piping the spring sources to end users depends on their distances from each other and their microbiological characteristics. Previous studies indicate that the E coli counts vary from one spring to the other (Table 5) and these are higher during the rainy season than during the dry season (Guemuh, 2003). Based on Table 5 , the springs can be classified in decreasing order of purity as follow:

$\mathrm{S}_{5}$ (Foreke) $-\mathrm{S}_{1}$ (California) $-\mathrm{S}_{4}$ (Madagascar) - $\mathrm{S}_{3}$ (Gendarmerie) - $\mathrm{S}_{2}$ (Pentagon)

$\mathrm{S}_{5}$ is the purest spring and $\mathrm{S}_{2}$ is very unacceptable.

The springs $S_{1}$ and $S_{2}$ are located in the same vicinity at about $500 \mathrm{~m}$ from each other yet their bacteriological characteristics are very different. To harness spring $S_{2}$ for drinking purposes, it has to be treated with calcium hypochlorite. To ensure the water is safe for drinking, the water must have a residual amount of chlorine. The chlorination should be carried out after remineralisation as indicated in figure 3. If such a treatment is carried out, springs $S_{1}$ and $S_{2}$ could be used to supply the Paid Ground neighbourhood. However, a regular monitoring of the Pentagon spring, $\mathrm{S}_{2}$, will avoid unpleasant surprises especially in the rainy season when fecal contamination is more pronounced.

The springs $S_{3}$ and $S_{4}$ are located in the Administrative centre and the Madagascar neighbourhoods respectively about $600 \mathrm{~m}$ from each other. If $S_{3}$ is of poor quality, $S_{4}$ on the other hand is of acceptable quality (less that 10 E.coli/100 $\mathrm{ml}$ of water, Table 5). If these two springs also undergo the same treatment as shown in figure 3 , they could be used to supply their respective neighbourhoods.

Spring $S_{5}$ is $2 \mathrm{~km}$ far from spring $S_{3}$. For economic reasons a piped network could only serve the Foreke neighbourhood where it is located. It is a spring which is always in use and is located in a neighbourhood of a high population density and paradoxically is the purest in terms of the E. coli count (Table 5). As such, with a stricter control it could supply water to the neighbourhood without any disinfection. However residual chlorine in the water mains resulting from the treatment with calcium hypochlorite will ensure disinfection of the water. 
Table 5: The variability of the E.coli count of the different springs.

\begin{tabular}{llllllllll}
\hline Sample & January & February & March & April & May & June & July & August & Mean \\
\hline California & 4 & 3 & 3 & 7 & 9 & 9 & 30 & 10 & 9 \\
Pentagon & 17 & 18 & 12 & 30 & 30 & 25 & 90 & 20 & 30 \\
Gendarmerie & 3 & 18 & 9 & 5 & 20 & 18 & 20 & 30 & 15 \\
Madagascar & 5 & 30 & 9 & 6 & 9 & 9 & 5 & 5 & 10 \\
Foreke & 2 & NA & 3 & 12 & 18 & 17 & 7 & 4 & 9 \\
\hline
\end{tabular}

(Source: Guemuh, 2003)

Due to the fact that during the dry season there is a reduction in the water flow rate of springs, it is prudent to envisage a borehole to augment the quantity of water available during this period.

From the foregoing it is evident that three mini water distribution network can be envisaged to supply water to the following neighbourhoods: Paid ground using $S_{1}+S_{2}$, the Administrative centre and Madagascar using $\mathrm{S}_{3}+\mathrm{S}_{4}$ and Foreke using $\mathrm{S}_{5}$. Pumping will therefore be required.

\section{Conclusions}

The study reveals that the waters are soft as such good for washing and for cooking vegetables. However they are very aggressive and would corrode metallic conduits. Due to their aggressivity and their low level of mineralization they need corrective treatment to improve upon the total hardness, total alkalinity and to bring it to the calco-carbonic equilibrium. For this purpose, chemical treatment with calcium carbonate will be economical. Also, the spring waters need disinfection prior to distribution, therefore calcium hypochlorite is recommended as the disinfection agent.

In order to ensure provision of water to the population without access to the piped water supplied by SNEC, three mini distribution networks can be constructed with the aim of bringing water closer to consumers. To avoid corrosion, the distribution network should be made of resistant material, preferably PVC.

Natural waters are generally soft in tropical regions and are consequently aggressive. Before distribution through a network, such waters should undergo similar correction treatment as indicated in this study.

A heavy metal analysis is recommended to be carried out to complement the study. This needs very sophisticated techniques such as polarography which is beyond our reach at the moment.

\section{REFERENCES}

CEE (Communauté européenne). 1975. Normes de potabilisation des eaux. Journal Officiel des Communautés Européennes.

Champaud. 1973. Atlas Régional de l'Ouest II. Document ORSTOM.

Collienne RH, De Graeve JC. 1973. Agressivité des eaux vis-à-vis du plomb et contamination alimentaire dans l'est de Belgique. Tech-Eau-Assainissement, 315 : 17-28.

Fletcher G. 1986. Groundwater and Wells. Johnson Filtration Systems Inc.: Minnesota, USA.

Guemuh GN. 2003. Quality of domestic water supply in Dschang and effectiveness of some locally used treatment methods. "Ingénieur Agronome" thesis. Department of Agricultural Engineering. FASA, University of Dschang, Cameroon, p. 58.

Guilleret JR, Kayem J, Molleyre F, Roques M. 1990. L'agressivité des eaux de surface en région tropicale. Ses conséquences sur le réseau de distribution. Tech. Sci. Meth, 85(3): 123126.

Jaeger Y, Oberti S, Guichot L, Baron J. 2005. Comparaison de traitements utilisés pour limiter la corrosivité des eaux douces dans les réseaux de distribution d'eau potable. Journal Européen d'Hydrologie. 36(2): 191-207.

Jones GJ, Gardener S, Simon BM. 1993. Bacterial reduction of ferric iron in a stratified eutrophic lake. J. Gen. Microb., 129: 131-139.

Kamgaing T. 1993. Contribution à l'étude de l'adoucissement chimique des eaux naturelles. Thèse de doctorat $n^{\circ} 865$, 
Université de Rennes 1, France, p.126, annexe (p.32)

Kamgaing T. 2003. Caractère agressif des eaux du Lac Nyos (Ouest-Cameroun). Impacts du dégazage de l'hypollimnion et suggestions. Tech. Sci. Meth., 10: 59-65.

Kwekam M. 1993. Le massif plutonique calco-alcalin pan-africain de Fomopéa (Ouest-Cameroun): cadre structural, pétrologie-Géochimie. Interprétation géodynamique. Thèse Doctorat 3è cycle, Université Yaoundé 1, P.154

Legrand L, Poirier G. 1976. Chimie des Eaux Naturelles. Eyrolles: Paris.

Legrand L, Poirier G, Leroy P. 1981. Les Equilibres Carboniques et l'Equilibre Calco-carbonique dans les Eaux Naturelles . Eyrolles: Paris.

Marchand A, Dorange G, Le Guyader M. 1985. Influence des paires d'ions sur l'établissement de la courbe d'équilibre calcocarbonique dans le système $\mathrm{CO}_{2 \mathrm{~T}^{-}}$ $\mathrm{Ca}^{2+}$. Trib. Cebedeau, 38(501): 9-18.

Mohr ECJ, Van Baren FA, Van Schuylenborgh J. 1972. Tropical Soils. A Comprehensive Study of their Genesis $\left(3^{\text {rd }}\right.$ edn, revised and enlarged). Geuze Dordrecht: The Netherlands.

Moulinier Y. 1998. Rapport de la commission d'expertise technique effectuée du 5 au 12 Juillet 1998 à Dschang. GIE Granlac, p. 37.

Ngomediage E. 2001. Evaluation of the quantity and quality of some fresh water springs in Dschang central. "Ingénieur Agronome" thesis. FASA, University of Dschang, p. 55.

NIS (National Institute of Statistics). 2001. Cameroon Statistical Yearbook. Ministry of Economy and Finance: Yaoundé, Cameroon.

Nni J, Nyobe JB. 1995. Géologie et pétrologie des laves précaldériques des Monts Bambouto: Ligne du Cameroun. Geochim. Brazil, 9(1): 47-59.

Plummer LN, Busenberg E. 1982. The solubility of calcite, aragonite and vaterite in $\mathrm{CO}_{2}-\mathrm{H}_{2} \mathrm{O}$ solutions between 0 and 90 ${ }^{\circ} \mathrm{C}$, and an evaluation of the aqueous model for the system $\mathrm{CaCO}_{3}-\mathrm{CO}_{2}-\mathrm{H}_{2} \mathrm{O}$. Geochim. Cosmochim. Acta, 46: 10111040.

Rheinheimer G. 1980. Aquatic Microbiology $\left(2^{\text {nd }}\right.$ edn). John Wiley \& Sons.

Rodier J. 1984. L'analyse de l'Eau (7 $7^{\mathrm{e}}$ edn). Dunod: Paris.

Rondia D, Sartor F. 1978. Conséquences pour la santé d'une interaction entre l'eau potable douce et les matériaux. Trib. De Cebedeau, 419: 341-347.

Simo PJN. 2006. Procéssus hydrochimiques et géochimiques sur le versant sud des Monts Bambouto (Ouest-Cameroun). Mémoire de Master of Science en Géologie de l'environnement, Université de Dschang, p. 95.

Tabue YJG. 2001. Influence de la nature lithologique et des structures géologiques sur la qualité des eaux de source. Cas du secteur Fokamezoung-Doumbwo (SudEst de la ville de Dschang, OuestCameroun). Mémoire de Maîtrise en Sciences de la Terre, Université de Dschang, p. 99.

Tekoudjou H. 2004. Etude de la variabilité pluviométrique sur le flanc sud des Monts Bambouto. Mémoire de DEA en Sciences de la Terre, Université de Yaoundé 1, p. 47.

Twort AC, Hoather RC, Law FM. 1982. Water Supply. Edward Arnold Publishers Ltd: London.

Vofo EB. 2001. Etude de quelques propriétés chimiques des eaux de source et de puits consommées dans la ville de Dschang. Mémoire de Maîtise de Chimie, Université de Dschang, p.34.

Vogel AI. 1962. Quantitative Organic Analysis ( $3^{\text {rd }}$ edn). Longman Group: London.

WHO (World Health Organisation). 1993. Guidelines for Drinking Water Quality, $2^{\text {nd }}$ Recommendations: WHO: Geneva.

WHO (World Health Organisation). 1997. Guidelines for Drinking Water Quality: Recommendations, Health Criteria and other Supporting Information ( $2^{\text {nd }}$ edn). Vol. 3. WHO: Geneva. 